\title{
Expression of levansucrase- $\beta$-galactosidase hybrids inhibits secretion and is lethal in Bacillus subtilis
}

\author{
Monique ZaGoReC* and Michel SteinMetZ \\ Laboratoire de Génétique des Micro-organismes, INA-PG CBAI, 78850 Thiverval-Grignon, France
}

(Received 4 December 1989; revised 16 February 1990; accepted 5 March 1990)

\begin{abstract}
The lac Z gene of Escherichia coli was fused to several positions downstream from the $5^{\prime}$ end of the Bacillus subtilis $\operatorname{sac} B$ gene, which encodes levansucrase (LS), a sucrose-inducible extracellular enzyme. Effects of hybrid protein expression in B. subtilis were studied. Several fusions were tested, and two significantly interfered with growth of cells and with IS secretion when induced with sucrose. Chromosomal amplification of the fusions, leading to strong expression of the hybrid proteins, completely blocked LS secretion and was lethal for B. subtilis when expression was induced.
\end{abstract}

\section{Introduction}

Bacilli secrete a number of enzymes (Priest, 1977). Despite several of these proteins being industrially produced, basic research on secretion in these bacteria is as yet poorly developed. Biochemical studies have shown the existence in Bacillus subtilis of an ' $\mathrm{S}$ complex' consisting of four proteins. This complex has two forms: a free cytoplasmic form, and a form bound to membraneassociated ribosomes (Caulfield et al., 1985). An analogous, immunologically related complex was described in Staphylococcus aureus (Adler \& Arvidson, 1984), and the genes encoding these four staphylococcal proteins have recently been cloned in Escherichia coli. They are clustered in a $5.9 \mathrm{~kb}$ DNA fragment. They seem to be essential in $S$. aureus, since their inactivation could not be obtained (Adler \& Arvidson, 1988). The exact function of these complexes in the secretion process has yet to be clearly demonstrated. Secretory mutants of $B$. subtilis have been isolated; the mutations, which decrease the secretion of $\alpha$-amylase, mapped in four different loci (Kontinen \& Sarvas, 1988).

The genetic study of secretion in $E$. coli has largely used fusions between the $\mathrm{NH}_{2}$-terminal part of proteins which are normally translocated and $\beta$-galactosidase (for reviews see Bankaitis et al., 1985; Beckwith \& Silhavy, 1983). Two approaches have been developed. First, taking advantage of the lethality caused by the high expression of some of these fusions, mutations affecting the signal peptide of translocated proteins have been

Abbreviation: LS, levansucrase. isolated (Oliver \& Beckwith, 1981). Secondly, hybrids have been used as tools to isolate mutants affected in the secretion apparatus. An analogous strategy has recently been used in Saccharomyces cerevisiae (Deshaies \& Schekman, 1987).

We have initiated this kind of approach to isolate secretory mutants in $B$. subtilis. We used a sucroseinducible gene, $s a c B$, encoding the exoenzyme levansucrase (LS), whose expression can be further modulated depending on the genetic background (Aymerich et al., 1986). In this paper, we describe the construction of $s a c B$ : : lac $Z$ hybrid genes and the analysis of the effects of their expression.

\section{Methods}

Plasmids and construction of $\operatorname{sacB}:$ : lac Z fusions. $\operatorname{sacB}::$ lac $Z$ fusions were generated from the plasmid pLS153-Z. This plasmid was constructed in several steps from three plasmid DNA sources already described: pLG131 (Aymerich et al., 1986), pLS153 (Steinmetz \& Aymerich, 1986) and pUC19 (Yanisch-Perron et al., 1985). pLS153-Z contains the sacB gene 625 bp upstream from the $l a c Z$ gene, in the same orientation (Fig. 1). Upstream from the $5^{\prime}$ end of the lac $Z$ gene a polylinker is present but no transcriptional or translational initiation signals. This plasmid is replicative in E. coli but not in B. subtilis. pHVA, which is replicative in both hosts and confers erythromycin resistance upon $B$. subtilis, is a derivative of pHV1201 (Noirot et al., 1987) from which HindIII/PvuII fragment has been deleted; it contains a single region homologous to pLS153-Z and its derivatives.

To construct fusions, Bal31 deletions of 0 to $1 \mathrm{~kb}$ were generated from the single $H$ indIII site, located at the $3^{\prime}$ end of $s a c B$ (Fig. 1, A). The DNA was then cut with SalI, the single-strand termini were endfilled with Klenow fragment, and ligated. The ligation mixtures were 


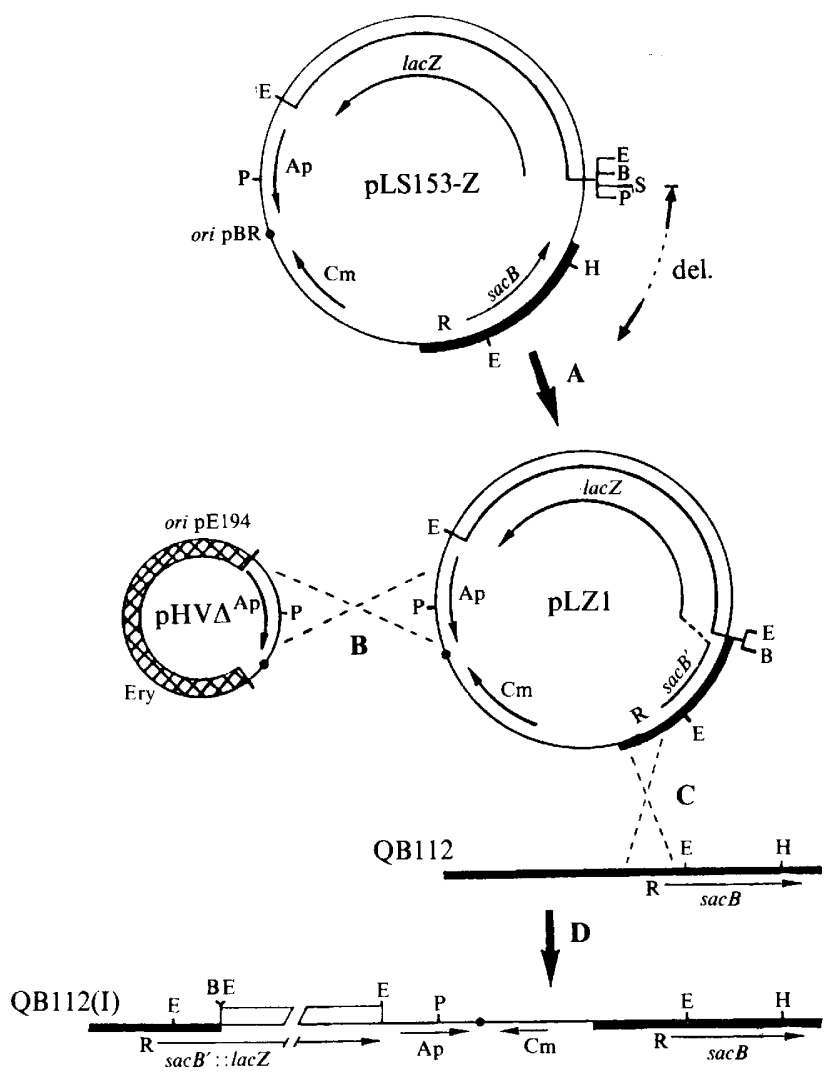

E Amplifiable region

Fig. 1. Construction of $s a c B:: l a c Z$ fusions and their insertion into the $B$. subtilis chromosome. pLS153-Z was constructed in several steps: the PstI-Pst Iragment containing $s a c B$ is from pLS153; the Pst $\mathrm{I}-$ BamHI fragment containing lacZ is from pLG131; the BamHI-PstI linker, between $s a c B$ and $l a c Z$, is from pUC19. A, Fusions, such as $\mathrm{pLZ1}$, were generated by deletion (del.). B, These constructions were first inserted into $\mathrm{pHV} \Delta$ by homologous recombination. $\mathrm{C}$, Second, the fusions were inserted into the chromosome of B. subtilis QB112. This gave QB112(I), whose chromosomal structure is shown (D); the amplifiable region is indicated by the double-headed arrow (E). B, E, H, P and S: BamHI, EcoRI, HindIII and $S a l$ restriction sites, respectively, ori $\mathrm{pBR}$ and ori pE194: origins of replication of pBR322 and pE194, respectively. R: the $s a c R$ region (promoter plus regulatory sites of $s a c B$ ). Ap, $\mathrm{Cm}$ and Ery: genes for resistance to ampicillin, chloramphenicol and erythromycin, respectively.

used to transform competent cells of B. subtilis strain GM417, which contains pHV $\Delta$, to chloramphenicol resistance. This strain carries a large deletion at the sacB locus (Steinmetz et al., 1985), in order to prevent integration of the $\mathrm{pLS} 153-\mathrm{Z}$ derivatives into the chromosome by homologous recombination of $s a c B$. Recombination at the level of the homologous region between pHVA and pLS153-Z deleted derivatives such as pLZ1 generated replicative hybrids (Fig. 1, B).

Plasmid DNA extracted from GM417 transformants was then introduced into the weakly transformable $B$. subtilis strain QB112 carrying the sacU32 mutation. Since QB112 is $\operatorname{sac} B^{+}$, hybrid plasmids can either replicate or integrate into the chromosome at the $s a c B$ locus (Fig. 1, C, D). The replication origin of pHV $\Delta$ is inefficient at high temperature. In order to select insertions into the chromosome, QB112 transformants were selected for chloramphenicol resistance at $46^{\circ} \mathrm{C}$. The majority of transformants were expected to contain a complete hybrid plasmid inserted at the $s a c B$ locus, a second selection step being required to select excision and loss of pHVA (Noirot et al., 1987). Surprisingly, most transformants were erythromycin sensitive. Perhaps the residual replication ability of $\mathrm{pHV} \Delta$ at $46^{\circ} \mathrm{C}$ was sufficient to promote its excision from the chromosome but insufficient to allow its maintenance in a replicative form.

Strains. B. subtilis strains used in this study are listed in Table 1. E. coli strain TG1 [ $\triangle($ lac-pro $)$ supE thi hsdD5 $\left(\mathrm{F}^{\prime}\right.$ traD36 proA $A^{+} B^{+}$lacI ${ }^{q}$ lac $Z \Delta \mathrm{M} 15)$ ] (Gibson, 1984) was used for propagation of plasmid DNA.

Media, cultures and phenotypic characterization on solid media. Competent cells of $B$. subtilis were transformed as described by Anagnostopoulos \& Spizizen (1961). Transformants were selected on LB plates (Miller, 1972) containing chloramphenicol $\left(4 \mathrm{mg} \mathrm{l}^{-1}\right)$ or erythromycin $\left(0 \cdot 3 \mathrm{mg} \mathrm{l}^{-1}\right)$. E. coli transformants were selected on LB plates containing ampicillin $\left(50 \mathrm{mg} \mathrm{l}^{-1}\right)$ or chloramphenicol (18 $\left.\mathrm{mg}^{-1}\right)$.

For phenotypic characterization, $\mathrm{C}$ mineral medium (Aymerich et al., 1986) was used. CG medium is $\mathrm{C}$ medium supplemented with glucose $\left(1 \mathrm{~g} \mathrm{l}^{-1}\right.$ for plates and $10 \mathrm{~g} \mathrm{l}^{-1}$ for liquid medium). Sucrose sensitivity was tested by replica plating clones on CG plates with or without sucrose $\left(20 \mathrm{~g} \mathrm{l}^{-1}\right) . \beta$-Galactosidase activity was detected by addition of X-Gal $\left(20 \mathrm{mg} \mathrm{l}^{-1}\right)$ to plates.

Growth in liquid CG medium was monitored by optical density measurements at $600 \mathrm{~nm}\left(\mathrm{OD}_{600}\right)$. Expression of $\beta$-galactosidase, LS and fusions in liquid media was induced by addition of sucrose $\left(20 \mathrm{~g}^{-1}\right)$ at $0 \cdot 20 \mathrm{OD}_{600}$.

Determination of $\beta$-galactosidase and LS activity. Cells were grown in liquid culture and $1.5 \mathrm{ml}$ samples were removed. Cells were then lysed as described by Aymerich et al. (1986). $\beta$-Galactosidase activity was determined by the method of Miller (1972) and is expressed as Miller units $\mathrm{ml}^{-1}$.

LS activity in culture supernatants dialysed against 0.05 M-potassium phosphate buffer $\mathrm{pH} 6.0$ was assayed by sucrose hydrolysis (Kunst $e t$ al., 1974). LS activity is expressed in $\mathrm{mU} \mathrm{ml}^{-1}$. One unit of LS liberates one $\mu \mathrm{mol}$ glucose $\mathrm{min}^{-1}$.

Chromosomal amplification. Plasmids inserted into the chromosomal $s a c B$ locus can be amplified by a method derived from Jannières $e t$ al. (1985). Cells grown overnight in LB containing $18 \mathrm{mg}$ chloramphenicol $1^{-1}$ were inoculated in LB containing $50 \mathrm{mg}$ chloramphenicol $\mathrm{l}^{-1}$ and incubated overnight. Clones containing several copies of the inserted plasmid grow on $18 \mathrm{mg}$ chloramphenicol $\mathrm{l}^{-1}$ as rapidly as the original strains on $4 \mathrm{mg}$ chloramphenicol $\mathrm{1}^{-1}$.

The amplification rate expected from such selection is 3 to 10 copies. The copy number of lac $Z$ genes was estimated in strains QB112(+)n and QB112(II)n by dot-blot hybridization as described by Declerck $e t$ al. (1988). The copy number was estimated to be 4 to 8 in the amplified strains when compared to the standards QB112 (0 copy) and QB112(+) (1 copy).

DNA sequencing. The plasmids containing fusions I and II could not transform $E$. coli (see Results). Thus, derivatives containing a frame shift between the $s a c B$ and $l a c Z$ sequences were constructed. In QB112(I)n and QB112(II)n, which contain amplified fusions, the DNA fragments between two BamHI sites (Fig. 1, D, E) represent the pLS153-Z derivative plasmid, linearized at the junction between $s a c B$ and lac $Z$. DNA extracted from these strains as described previously (Declerck et al., 1988) was digested by BamHI. The termini were rendered blunt by DNA polymerase I (Klenow fragment). The DNA was self-ligated and used to transform $E$. coli TG1 to ampicillin resistance. Plasmids containing these modified constructions (a 4-base 
Table 1. Bacillus subtilis strains used

\begin{tabular}{|c|c|c|}
\hline Strain & Genotype & Reference \\
\hline QB112 & $\operatorname{trpC2} \operatorname{sac} U 32$ & Kunst et al. 1974 \\
\hline $\mathrm{CC} 23$ & $\operatorname{trpC2} \operatorname{sacA321} \Delta(\operatorname{sac} R-B) 23$ & Steinmetz et al. (1985) \\
\hline GM417 & as CC23 plus pHVA (replicative) & \\
\hline $\mathrm{QB} 112(+)$ & as QB112 plus sacR-B: :pLG131 & \\
\hline QB112(+)n & as QB112(+) with pLG131 amplified & \\
\hline QB112(I) & as QB112 plus $s a c R-B:: \mathrm{pLZ1}$ & This work \\
\hline QB112(I)n & as QB112(I) with pLZ1 amplified & \\
\hline QB112(II) & as QB112 plus $s a c R-B:: \mathrm{pLZ2}$ & \\
\hline QB112(II)n & as QB112(II) with pLZ2 amplified & \\
\hline
\end{tabular}

addition at the $B a m H I$ site) were isolated from TGI transformants, and the small $E c o$ RI fragment containing part of $s a c B$ and the junction with lacZ (see Fig. 1) was cloned in M13mp18. The sequence was determined using the dideoxy termination method (Sanger et al., 1977).

Immunodetection experiments. Intracellular LS and hybrid proteins were detected by Western blot experiments. Bacterial extracts (the proteins TCA precipitated from lysed bacteria, corresponding to $\mathbf{0 \cdot 2}$ $\mathrm{OD}_{600}$ units of centrifuged culture samples) were subjected to electrophoresis on $10 \%(\mathrm{w} / \mathrm{v})$ polyacrylamide gels (Laemmli, 1970). Proteins were electrotransferred onto nitrocellulose membranes (Burnette, 1981) and incubated with rabbit antibodies raised against LS (a kind gift from M. F. Petit-Glatron, Institut Jacques Monod, Paris, France) or mouse anti- $\beta$-galactosidase antibodies (Promega Biotech). Anti-mouse or anti-rabbit IgG alkaline phosphatase conjugates (Promega Biotech) were used for detection and staining.

\section{Results}

Construction of sacB : : lacZ fusions

Plasmids containing the $5^{\prime}$ end of $\operatorname{sac} B$ fused to the $l a c Z$ gene were obtained by Bal31 deletion of pLS153-Z (Fig. 1, A). The $\operatorname{sacB}$ promoter is constitutive in $E$. coli (Steinmetz et al., 1985), and the expression of some sacB : : lac Z fusions might be lethal in E. coli. Therefore, to avoid such a bias in the selection, the ligation mixture was used to transform $B$. subtilis strain GM417, which is wild-type (inducible) for $s a c B$ expression. The fusions were maintained in this strain in a plasmid form by homologous recombination with a resident plasmid (Fig. 1). Among the resulting transformants, about one-third were expected to contain a plasmid carrying an in-frame fusion between $s a c B$ and $l a c Z$ leading to a hybrid gene. By replica plating on $C G$ plates with and without sucrose, the possible inhibitory effect of expression of hybrid genes was analysed in 155 transformants. No clear growth differences in the presence or absence of sucrose were observed, probably because $s a c B$ is poorly transcribed in wild-type strains (Shimotsu \& Henner, 1986).

In order to test the effects of strong expression of fusions, a $B$. subtilis strain carrying the sacU32 mutation, which strongly enhances $s a c B$ transcription (Shimotsu \&
Henner, 1986), was used. Plasmid DNA extracted from 23 GM417 transformants was used to transform strain QB112 (sacU32) to chloramphenicol resistance. The constructions were maintained in this strain by recombination with the chromosomal sacB locus (Fig. 1, C, D). Plasmid pLG131, which is similar to pLS153-Z derivatives but contains the $l a c Z$ open reading frame fused to the first codon of $s a c B$ (Aymerich et al., 1986), was used as a control. pLG131 was introduced into the chromosome of strain QB112 and the resulting strain called QB112(+). In the QB112 transformants, one copy of the fusion and one copy of intact $\operatorname{sac} B$ were present, each under the control of separate copies of the $\operatorname{sac} B$ promoter. The presence of the $\operatorname{sacB}$ gene permitted the study of the effect of fusion protein expression on LS secretion.

QB112 transformants carrying pLS153-Z derivatives were examined by replica plating on various media with or without sucrose. Two strains, carrying fusions numbered I and II, showed altered growth patterns on CG plates containing sucrose. This sucrose sensitivity was very slight in the case of construction I and more significant with construction II. QB112(+) and transformants carrying the 21 other constructions showed no sucrose sensitivity. Strains carrying fusions I and II were named QB112(I) and QB112(II), respectively. QB112(I) and QB112(II) were plated on X-Gal plates in the presence and absence of sucrose. Both strains displayed sucrose-inducible expression of $\beta$-galactosidase activity.

To determine whether sucrose sensitivity could be enhanced by increasing the level of expression of the fusions, plasmids integrated into the chromosome were amplified (Fig. 1, E). Amplification was selected by growing the QB112 transformants in liquid LB medium containing increased levels of chloramphenicol (Jannières et al., 1985). The resulting strains, which contained 4 to 8 copies of the respective fusion, were named QB112(I)n, QB112(II)n and QB112(+)n, respectively. These strains and the parental strains were tested by replica plating. Amplification of pLG131 led to increased lac $Z$ expression in the presence of sucrose and 

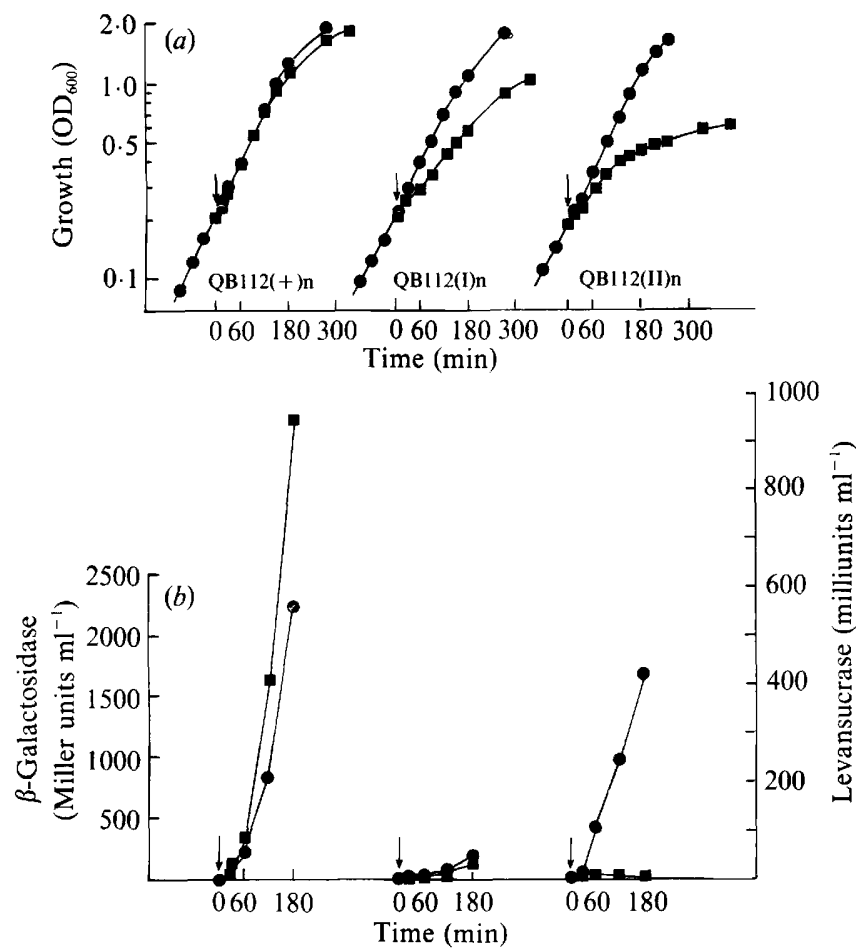

Fig. 2. Effects of fusion expression on growth and LS secretion. Strains QB112n(+), QB112n(I) and QB112n(II) were grown in CG medium. Induction was performed at $\mathrm{OD}_{600}=0.2$ by addition of sucrose (arrows). (a) Growth curves of strains in inducing $(\boldsymbol{\square})$ or non-inducing (O) conditions. (b) Activity of $\beta$-galactosidase ( $\mathbf{O}$ ), assayed in bacterial extracts, and LS ( $\square$ ), assayed in culture supernatants, after induction by sucrose (arrows)

had no effect on bacterial growth. On the other hand, QB112(I)n and QB112(II)n were unable to grow on CG plates containing sucrose. Thus sucrose sensitivity correlated with the expression level of these fusions.

\section{Effects of fusion expression on cell growth and $L S$ secretion}

The growth of strains containing amplified fusions in CG liquid medium in the presence or absence of sucrose was examined (Fig. 2a). Growth was slowed in strains containing fusions I and II following the addition of sucrose. Growth of strain QB112(II)n was almost completely stopped after 3 to $4 \mathrm{~h}$ induction. Sucrose not only affected growth, but irreversibly poisoned the cells. Samples taken from cultures after $3 \mathrm{~h}$ of induction were diluted and plated on LB plates. For strain QB112(+)n, one $\mathrm{OD}_{600}$ unit corresponded to about $5 \times 10^{8}$ c.f.u. In the case of QB112(I)n and QB112(II)n, only $7 \times 10^{7}$ and $1 \times 10^{6}$ c.f.u. per $\mathrm{OD}_{600}$ unit, respectively, were obtained; furthermore, for both QB112(I)n and QB112(II)n, more than $85 \%$ of these colonies were not



Fig. 3. Immunodetection of $\beta$-galactosidase and fusions I and II in bacterial extracts. Strains QB112(+)n (+), QB112(I)n (I) and QB112(II)n (II) were grown on liquid CG medium and induced for $3 \mathrm{~h}$ by sucrose. Proteins from cell extracts were electrophoresed, electrotransferred onto nitrocellulose and immunodetected by anti- $\beta$-galactosidase IgG. $\beta$-Galactosidase and the fusions are indicated by arrowheads.

resistant to $18 \mathrm{mg}$ chloramphenicol $\mathrm{l}^{-1}$. They might therefore have resulted from loss of amplification. No loss of viability or amplification was observed in uninduced cultures.

LS and $\beta$-galactosidase activities were measured in culture samples after various times of induction. $\beta$ Galactosidase activity was not detected in culture supernatants of either the control strain, QB112(+)n, or strains expressing fusions I or II. Fig. $2(b)$ shows $\beta$ galactosidase and LS activities determined in bacterial extracts and culture supernatants, respectively. $\beta$-Galactosidase activities detected in QB112 $(+) n$ and QB112(II)n were similar and about ten times higher than in QB112(I)n. This could signify that the hybrid protein was poorly expressed, proteolysed or poorly active in QB112(I)n. Using anti- $\beta$-galactosidase antibodies, similar amounts of $\beta$-galactosidase were detected in the three strains (Fig. 3).

The expression of fusions I and II resulted in a strong decrease of LS activity in the supernatant (Fig. 2b). For QB112(I)n and QB112(II)n, this activity was respectively $3 \%$ and $0.5 \%$ of that observed in the control, QB112(+)n. 

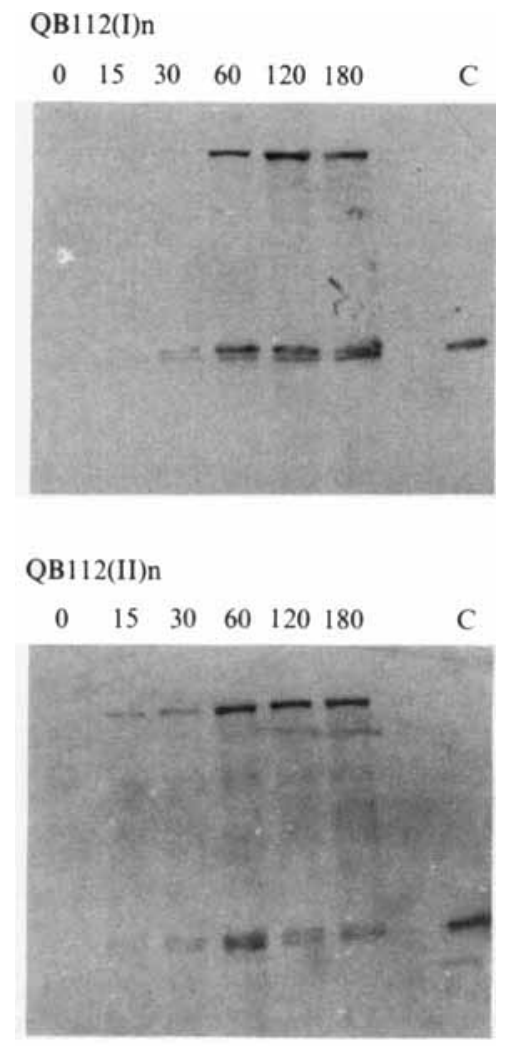

QB112(+)n

$\begin{array}{lllllll}0 & 15 & 30 & 60 & 120 & 180 & \mathrm{C}\end{array}$

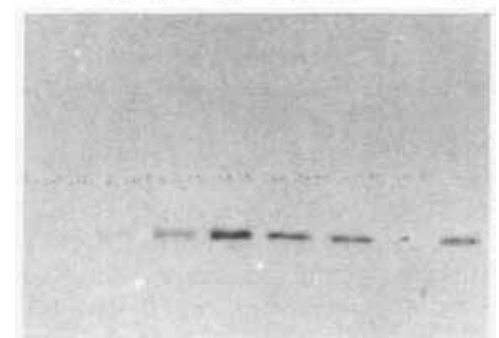

Fig. 4. Immunodetection of LS precursor and hybrid proteins in cellular extracts. Strains QB112(+)n, QB112(I)n and QB112(II)n were grown in CG medium and induced by sucrose. Culture samples were removed after $0,15,30,60,120$ and $180 \mathrm{~min}$ of induction. Proteins from the bacterial extracts were separated by electrophoresis on polyacrylamide gel, electrotransferred onto nitrocellulose and incubated with anti-LS antibodies. Lane C, purified LS.

\section{Accumulation of LS precursor}

In strain QB112, LS is synthesized as a precursor form containing a signal peptide. This precursor is rapidly cleaved into a membrane-processed form which is subsequently secreted into the medium. This processed form can be detected by Western-blotting experiments on bacterial extracts (Petit-Glatron et al., 1987).

Using antibodies raised against LS, the presence of LS precursor forms and LS- $\beta$-galactosidase hybrid proteins were analysed in extracts from QB112 transformants (Fig. 4). Both cleaved and uncleaved forms were accumulated in strains which expressed fusions I and II. The uncleaved form was not detected in strain QB112(+)n. The accumulation of LS precursor in QB112(II)n was very small and decreased after $2 \mathrm{~h}$. In strain QB112(I)n the level of LS precursor detected was higher: the uncleaved precursor appeared shortly after induction, and more of the cleaved form appeared subsequently (Fig. 4).

This result showed that strong expression of fusions I or II caused inhibition of LS secretion and was accompanied by accumulation of unsecreted LS precursor. Hybrid proteins, containing $\mathrm{NH}_{2}$-terminal parts of LS, were also detected by antibodies raised against LS (Fig. 4).

\section{Structure of fusions}

The positions of the junctions between $\operatorname{sacB}$ and $l a c Z$ in fusions I and II were determined by DNA sequencing. $E$. coli strain TG1 was transformed by the plasmids carrying these fusions and transformants were selected on LB plates containing ampicillin and chloramphenicol. An abnormally low transformation efficiency was observed as compared to transformations with constructions which did not confer sucrose sensitivity. The transformants contained mutated or rearranged derivatives of the original plasmids, and were therefore not informative (data not shown). Plasmids containing frame-shift mutations, which should abolish expression of the hybrid proteins, were constructed as described in Methods, by the addition of 4 bases at the BamHI site between sacB and lacZ (Fig. 1). The EcoRI fragment containing the fusion junction was sequenced. The 4-base insertion at the BamHI site was confirmed and the exact location of fusions between $\operatorname{sacB}$ and $l a c Z$ was deduced.

The fusions I and II contained, respectively, the first 191 and 216 codons of $s a c B$, including the region encoding the signal peptide. The $\operatorname{sac} B$ open reading frame is 473 codons long (Steinmetz et al., 1985). The deduced molecular masses of the corresponding proteins (140513 and $137935 \mathrm{Da}$ ) were in accordance with those estimated by electrophoresis (Fig. 3).

\section{Discussion}

Hybrid proteins containing $\mathrm{NH}_{2}$-terminal parts of translocated proteins fused to $\beta$-galactosidase have been useful tools in the genetic study of secretion in $E$. coli. This paper reports the construction of an analogous system in the Gram-positive B. subtilis. lac $Z$ fusions to the inducible $\operatorname{sac} B$ gene were constructed, and when they were induced in a wild-type strain, no lethal effects were 
observed. However, when expression was increased, using the mutant QB112, lethality was obtained. The sacU32 mutation in QB112 increases transcription from the $s a c B$ promoter about 100 -fold (Shimotsu \& Henner, 1986). In QB112 the fully induced level of LS represents $8 \%$ of total protein synthesis and LS is almost the only secreted protein during exponential growth (Chambert \& Petit-Glatron, 1984).

Two fusions among 23 constructions tested conferred sucrose sensitivity upon QB112. Amplification of these fusions increased that sensitivity. Their expression was accompanied by a severe decrease in LS secretion (Fig. 2). This decrease could not have been caused by titration of a positive regulator of $s a c B$ transcription, since the reference strain, QB112(+)n, also contained multiple copies of the $s a c B$ promoter-regulatory region and showed no such effect. The concomitant accumulation of uncleaved LS precursor in the sucrose-sensitive strains (Fig. 4) led to the conclusion that the decrease in LS was the consequence of inhibition of secretion. This represents the first report of such a phenomenon in $B$. subtilis.

The LS- $\beta$-galactosidase fusion II is only 20 amino acids longer than the fusion I. However, they did not cause exactly the same effects. Fusion II was more toxic than fusion I, caused a stronger inhibition of LS secretion and also possessed a higher $\beta$-galactosidase activity. This difference was observed both for QB112 transformants carrying several copies of the fusions (this paper) and for those carrying only one copy (data not shown). A partially analogous observation was reported in the case of lamB : : lac $Z$ fusions in $E$. coli. When a substantial part of $\operatorname{lam} B$ was present upstream from lac $Z$, induction by maltose was lethal. An exception was described: this fusion led to a hybrid protein which was both far less active and also conferred a weaker maltose-dependent toxicity than the others (Hall et al., 1982). Our observation is based on only two fusions. It should therefore be interesting to analyse the effects of further different fusions on the growth of $B$. subtilis and its secretion pathways.

In $S$. cerevisiae, hybrid proteins containing $\beta$-galactosidase fused to the $\mathrm{NH}_{2}$-terminal end of a matrix protein could be imported into mitochondria (Keng et al., 1986). In E. coli, the export to the periplasm of cytoplasmic proteins has been reported (Copeland et al., 1986; Takahara et al., 1988) but it appears difficult to translocate $\beta$-galactosidase fusions. The $S$. cerevisiae $S U C 2$ gene, which encodes a secreted invertase, was used in similar experiments. $S U C 2:$ : lac $Z$ fusions have been expressed in $S$. cerevisiae but the hybrid proteins did not pass beyond the endoplasmic reticulum and were not secreted (Emr et al., 1984). Expression of such fusions was apparently not lethal in yeast but this could be due to a relatively low level of expression of $S U C 2$. The protein products of $s a c B$ : :lac $Z$ fusions in $B$. subtilis, like the $S U C 2$ : : lac $Z$ fusions in yeast, were not translocated and low levels of expression were not lethal. However, at high levels of expression they behaved like those in E. coli, that is they were lethal. The reason for this effect of expression level has not been investigated. Nevertheless, using high levels of expression of fusion proteins, the selection of secretion mutants should be possible.

We are grateful to H. Heslot and C. Gaillardin for their encouragements and to A. Edelman for correcting this manuscript. This work was supported by research funds from the Ministére de la Recherche. M. Zagorec was supported by a grant from the 'Contrat Couples Hotes-Vecteurs Performants'.

\section{References}

ADLER, L. A. \& ARVIDSON, S. (1984). Immunological cross-reaction between proteins supposed to be involved in protein secretion in Staphylococcus aureus and Bacillus subtilis. FEMS Microbiology Letters 23, 17-20.

AdLeR, L. A. \& ARvidson, S. (1988). Cloning and expression in Escherichia coli of genes encoding a multiprotein complex involved in secretion of proteins from Staphylococcus aureus. Journal of Bacteriology 170, 5337-5343.

Anagnostopoulos, C. \& Spizizen, J. (1961). Requirements for transformation in Bacillus subtilis. Journal of Bacteriology 81, 741746.

Aymerich, S., Gonzy-Treboul, G. \& Steinmetz, M. (1986). 5 ' non coding region $s a c R$ is the target of all identified regulation affecting the levansucrase gene in Bacillus subtilis. Journal of Bacteriology 166, 993-998.

Bankaitis, V. A., Ryan, J. P., Rasmussen, B. A. \& Bassford, P. J. (1985). The use of genetic techniques to analyse protein export in Escherichia coli. Current Topics in Membranes and Transport 24, 105150.

BeCKWITH, J. \& Silhavy, T. J. (1983). Genetic analysis of protein export in Escherichia coli. Methods in Enzymology 97, 3-11.

BuRNETTE, W. N. (1981). 'Western blotting': electrophoretic transfer of proteins from sodium dodecyl sulfate polyacrylamide gels to unmodified nitrocellulose and radiographic detection with antibody and radioiodinated protein A. Analytical Biochemistry 112, 195-203.

Caulfield, M. P., Furlong, D., Tai, P. C. \& Davis, B. D. (1985). Secretory $\mathbf{S}$ complex of Bacillus subtilis forms a large, organized structure when released from ribosomes. Proceedings of the National Academy of Sciences of the United States of America 82, 4031-4035.

Chambert, R. \& Petit-Glatron, M. F. (1984). Hyperproduction of exocellular levansucrase by Bacillus subtilis: examination of the phenotype of a sac $U^{\text {h }}$ strain. Journal of General Microbiology 130, $3143-3152$.

Copeland, B. R., Su, T. Z. \& Oxender, D. L. (1986). Export of leucine-binding proteins and protein hybrids in Escherichia coli. In Microbiology - 1986, pp. 266-269. Edited by D. Schlessinger. Washington, DC: American Society for Microbiology.

Declerck, N., Joyet, P., Le CoQ, D. \& Heslot, H. (1988). Integration, amplification and expression of the Bacillus licheniformis alpha-amylase gene in Bacillus subtilis chromosome. Journal of Biotechnology 8, 23-38.

Deshaies, R. J. \& SCHEKMAN, R. (1987). A yeast mutant defective at an early stage in import of secretory protein precursor into the endoplasmic reticulum. Journal of Cellular Biology 105, 633-645.

Emr, S. D., Schauer, I., Hansen, W., Esmon, P. \& Schekman, R. (1984). Invertase $\beta$-galactosidase hybrid proteins fail to be transported from the endoplasmic reticulum in Saccharomyces cerevisiae. Molecular and Cellular Biology 4, 2347-2355.

Gibson, T. J. (1984). PhD thesis, University of Cambridge. 
Hall, M. N., Schwartz, M. \& Silhavy, T. J. (1982). Sequence information within the $\operatorname{lamB}$ gene is required for proper routing of the bacteriophage lambda receptor protein to the outer membrane of Escherichia coli K-12. Journal of Molecular Biology 156, 93-112.

Jannières, L., Niaudet, B. \& Ehrlich, S. D. (1985). Stable gene amplification in the chromosome of Bacillus subtilis. Gene 40, 47-55.

Keng, T., Alani, E. \& Guarente, L. (1986). The nine amino-terminal residues of $\delta$-aminolevulinate synthase direct $\beta$-galactosidase into the mitochondrial matrix. Molecular and Cellular Biology 6, 355-364.

Kontinen, V. P. \& Sarvas, M. (1988). Mutants of Bacillus subtilis defective in protein export. Journal of General Microbiology 134, 2333-2344.

Kunst, F., Pascal, M., Lepesant-Kejslarova, J., Lepesant, J. A., Billaut, A. \& Dedonder, R. (1974). Pleiotropic mutations affecting sporulation conditions and the synthesis of extracellular enzymes in Bacillus subtilis. Biochimie 56, 1481-1489.

LAEMmLI, U. K. (1970). Cleavage of structural proteins during the assembly of the head of bacteriophage T4. Nature, London 227, 680685 .

MilleR, J. (1972). Experiments in Molecular Genetics. Cold Spring Harbor, NY: Cold Spring Harbor Laboratory.

NoIrot, P., Petit, M. A. \& ERhlich, S. D. (1987). Plasmid replication stimulates DNA recombination in Bacillus subtilis. Journal of Molecular Biology 186, 39-48.

Oliver, D. B. \& BeCKWITH, J. (1981). E. coli mutant pleiotropically defective in the export of secreted proteins. Cell 25, 765-772.
Petit-Glatron, M. F., Benyahia, F. \& Chambert, R. (1987). Secretion of Bacillus subtilis levansucrase: a possible two step mechanism. European Journal of Biochemistry 163, 379-387.

Priest, F. G. (1977). Extracellular enzyme synthesis in the genus Bacillus. Bacteriological Reviews 41, 711-753.

SANGer, F., Nicklen, S. \& Coulson, A. R. (1977). DNA sequencing with chain terminating inhibitors. Proceedings of the National Academy of Sciences of the United States of America 74, 5463-5467.

SHIMOTSU, H. \& HeNNER, D. J. (1986). Modulation of Bacillus subtilis levansucrase gene expression by sucrose and regulation of the steadystate mRNA level by $\operatorname{sac} U$ and $\operatorname{sac} Q$ genes. Journal of Bacteriology $168,380-388$

Steinmetz, M., Le CoQ, D., Aymerich, S., Gonzy-Tréboul, G. \& GAY, P. (1985). The DNA sequence of the gene for the secreted Bacillus subtilis levansucrase and its genetic control sites. Molecular and General Genetics 200, 220-228.

SteinmetZ, S. \& Aymerich, S. (1986). Analyse génétique de sacR, régulateur en cis de la lévane saccharase de Bacillus subtilis. Annales de l'Institut Pasteur/Microbiologie 177A, 3-14.

TAKahara, M., SaGai, H., Inouye, S. \& Inouye, M. (1988). Secretion of human superoxide dismutase in Escherichia coli. Biotechnology 6 , 195-198.

YanisCh-Perron, C., Vieira, J. \& Messing, J. (1985). Improved M13 phage cloning vectors and host strains: nucleotide sequence of the M13mp18 and pUC19 vectors. Gene 33, 103-119. 